\title{
Evaluation of Serum Total Sialic Acid and Lipid Associated Sialic Acid as a Tumour Marker
}

\author{
G. Rajeswari ${ }^{1}$, P.S.Gopal ${ }^{1}$, P.Srilaxmi ${ }^{2}$, M.Farid Babu ${ }^{2}$, D.Rekha Kumari ${ }^{2}$ \\ 1.Professor \& Head,Department of Biochemistry,Rangaraya Medical College,Kakinada,Andhra Pradesh \\ 1.Assistant Professor, Department of Pharmacology,Rangaraya Medical College,Kakinada,Andhra Pradesh \\ 2.Department of Genetics, Osmonia University,Hyderabad,Andhra Pradesh \\ 2.Assistant Professor,Department of Biochemistry,Konaseema Institute of Medical Sciences \& Research \\ Foundation,Amalapuram, E.G district, Andhra Pradesh \\ 2.Assistant Professor,Department of Biochemistry, Konaseema Institute of Medical Sciences \& Research \\ Foundation,Amalapuram,E.G district, Andhra Pradesh
}

\begin{abstract}
The present study was done to assess the levels of total sialic acid \& lipid associated sialicAcid. Lactate dehydrogenase and total proteins in sera of patients with various malignant diseases and compared with sera of non malignant diseases, benign tumors \& controls. Serum total sialic acid, LASA \& LDH values are significantly increased in malignancies when compared to the controls $(P<0.001)$, indicating altered metabolism of tumour cell surface glycoprotein \& sialoglycolipids and there is decrease of total proteins in malignancies especially Gastro intestinal tract malignancies $(P<0.001)$. We had followed up 23 patients suffering from different malignancies and were received treatment. All these patients showed clinical improvement gradually at an end of 20 days followed up period. The TSA, LASA, \& LDH significantly decreased $(P<0.001, P<0.01, P<0.05)$ respectively. So this study suggests sialic acid as a tumour marker which shows good diagnostic potential.
\end{abstract}

Key Words: LASA, TSA, LDH \& Malignancies

\section{Introduction}

Sialic acid is a common terminal sugar unit of oligosaccharides of glycoproteins and glocolipids which are cell surface constituents. These are entered in circulation by either shadding of cell lysis and are considerable interest because of their potential diagnostic value. A variety of methods are available for in detection estimation of TSA \& LASA. Most widely used procedures are in colorimetric method. Here we were used colorimetric method because it is inexpensive simple to measure need not required sophistication easier, rapid and more suitable. [ 1 ] [ 3 ]. The dramatic changes in glycolipid composition and metabolism associated with oncogenic transformation suggests a specific role for membrane glycolipids in regulation of cell growth and cellular interaction. The two types of changes, one the deletion of complex glycolipids due to a block in synthesis, which leads to accumulation of precursor structures and the second the synthesis of new glycolipid due to activation of normally unexpressed glycosyl transferases can produce tumour distinative glycolipids, some of which are tumour associated antigens or markers. The present study was an attempt to the relative usefulness of TSA \& LASA for detecting malignancy and monitoring in progression of malignancy with treatment.

\section{Materials \& Methods}

92 patients with different malignances were studied. The results were compared with those of the controls 30 , non malignant diseases $30, \&$ benign tumours 20 . The study group is constituted by both in sexes and different age groups. The mean age of the patient is 48 years, Range 8 to 75 years. All the malignant cases are histologically confirmed of various types.

Table-1: Number \& type of Malignancies studied

\begin{tabular}{|l|l|l|}
\hline S. no & Type of Malignancy & No. of Cases \\
\hline 1. & Malignancies of head \& neck & 28 \\
\hline 2. & Malignancies of female genital tract & 22 \\
\hline 3. & Malignancies of GIT & 16 \\
\hline 4. & Malignancies of breast & 10 \\
\hline 5. & $\begin{array}{l}\text { Other malignancies(bone, penis, lung, lymphoma, } \\
\text { Leukemia, prostate) }\end{array}$ & 16 \\
\hline
\end{tabular}

Random blood samples were collected sera separated the sera were stored \& frozen $\left(-20^{\circ} \mathrm{c}\right)$ until used. The sera were analysed for TSA, LASA, LDH and total proteins. Estimation of serum TSA and LASA by 
[colorimetric method] plucinsky etal (13) Estimation of LDH by [colorimetric method] King etal and Estimation of serum total proteins by [colorimetric method] Henry's method. (4).

23 patients of different malignancies were followed up, samples were analysed before treatment 10 days after treatment and 20 days after treatment.

The data was statistically analysed. The mean and standard deviation values for each group for all parameters are calculated, followed up different malignant plus in (table 1). The significance of difference is assessed by student ' $\mathrm{t}$ ' test.

\section{Results}

The TSA, LASA and LDH values are increased in malignant patients when compared with controls $(\mathrm{P}<0.001)$ suggest increased metabolism in membrane glycolipids and glycoproteins. (10) (11).

Serum total proteins decreased in malignant patient when compared to the controls $(\mathrm{P}<0.01)$.

Total proteins were significantly decreased $(\mathrm{P}<0.001)$ in GIT malignances when compared to controls.

TSA, LASA values in malignances are higher than those non malignant diseases and benign tumours. The difference is statistically significant $(\mathrm{P}<0.001)$.

In order to assess the diagnostic sensitivity of the various parameters in reference ranges for them are calculated (mean ${ }_{-} 2$ standard deviation values) the reference ranges for various parameters are presented.

Table-2: Diagnostic sensitivity and specificities of various markers in malignancies

\begin{tabular}{|l|l|l|l|}
\hline S. no & Markers & Sensitivity \% & Specificity \% \\
\hline 1. & Total Sialic acid - (TSA) & 78.26 & 78.43 \\
\hline 2. & LDH & 69.57 & 62.75 \\
\hline 3. & TSA + LASA & 78.26 & 98.04 \\
\hline 4. & TSA + LASA + LDH & 91.3 & 100.0 \\
\hline 5. & LASA + LDH & 69.57 & 100.0 \\
\hline
\end{tabular}

Table- 3: Mean \& SD of various parameters in different Groups

\begin{tabular}{|l|l|l|l|l|l|l|}
\hline S.no & Group & No.of cases & $\begin{array}{l}\text { TSA } \\
\mathbf{m g} \%\end{array}$ & LASA mg\% & $\begin{array}{l}\text { LDH } \\
\text { IU } / \text { L }\end{array}$ & $\begin{array}{l}\text { Total proteins } \\
\text { gm \% }\end{array}$ \\
\hline 1. & Controls & 30 & $51.03=11.39$ & $18.16=6.94$ & $112.9=26.97$ & $6.1=0.37$ \\
\hline 2. & Benign tumours & 20 & $54.86=15.25$ & $1.67=8.07$ & $100.48=22.47$ & $6.15=0.3$ \\
\hline 3. & Non-malignant diseases & 30 & $66.27=8.85$ & $14.04=.83$ & $184.2=65.8$ & $5.9=0.66$ \\
\hline 4. & Total malignancies & 92 & $81.22=12.92$ & $26.95=7.08$ & $190.26=46.35$ & $5.84=0.48$ \\
\hline
\end{tabular}

Table 4: Mean \& SD of various parameters in different malignancies

\begin{tabular}{|l|l|l|l|l|l|l|}
\hline S. no & Malignancy type & $\begin{array}{l}\text { No. of } \\
\text { cases }\end{array}$ & $\begin{array}{l}\text { TSA } \\
\text { mg\% }\end{array}$ & $\begin{array}{l}\text { LASA } \\
\text { mg\% }\end{array}$ & $\begin{array}{l}\text { LDH } \\
\text { IU/L }\end{array}$ & Total proteins gm\% \\
\hline 1. & Head \& neck group & 28 & $82.32 \pm .67$ & $28.55 \pm 7.70$ & $187.57 \pm 51.25$ & $5.99 \pm 0.37$ \\
\hline 2. & Female genital tract group & 22 & $18.82 \pm .92$ & $23.81 \pm 5.97$ & $186.51 \pm 26.46$ & $5.92 \pm 0.46$ \\
\hline 3. & Gastro intestinal group & 16 & $85.63 \pm 13.25$ & $30.79 \pm 8.0$ & $200.62 \pm 41.06$ & $5.53 \pm 0.56$ \\
\hline 4. & Breast group & 10 & $75.90 \pm 5.23$ & $25.74 \pm 5.6$ & $188.0 \pm 73.91$ & $5.91 \pm 0.54$ \\
\hline 5. & other malignancies & 16 & $81.50 \pm 8.83$ & $25.35 \pm .38$ & $191.06 \pm 46.98$ & $5.71 \pm 0.41$ \\
\hline
\end{tabular}

Table 5: Mean \& SD of various parameters in followed up cases of malignancies

\begin{tabular}{|l|l|c|c|c|l|l|}
\hline S. no & Group & $\begin{array}{l}\text { No. of } \\
\text { cases }\end{array}$ & $\begin{array}{l}\text { TSA } \\
\text { mg\% }\end{array}$ & $\begin{array}{l}\text { LASA } \\
\text { mg\% }\end{array}$ & $\begin{array}{l}\text { LDH } \\
\text { IU/L } \\
\text { proteins } \\
\text { gm\% }\end{array}$ \\
\hline 1 & Malignancybefore treatment & 23 & $81.13 \pm 3.08$ & $26.34 \pm 7.65$ & $193.65 \pm 64.3$ & $5.8 \pm 0.41$ \\
\hline 2 & Malignancies 10 days after Rx & 23 & $74.52 \pm 2.37$ & $24.42 \pm 5.42$ & $168.13 \pm 71.58$ & $5.77 \pm 0.31$ \\
\hline 3 & Malignancies 20 days after the start of Rx & 23 & $69.0 \pm 9.77$ & $22.04 \pm 5.59$ & $161.91 \pm 56.29$ & $5.92 \pm 0.32$ \\
\hline
\end{tabular}

Table 6: ' $t$ ' and ' $p$ ' values of various parameters in followed up cases of malignancies

\begin{tabular}{|c|c|c|c|c|c|c|}
\hline S. no & Group & $\begin{array}{l}\text { No.of } \\
\text { cases }\end{array}$ & TSA & LASA & LDH & Total proteins \\
\hline 1 & $\begin{array}{l}\text { Malign before RX Vs } \\
\text { malign } 10 \text { days after Rx }\end{array}$ & $\begin{array}{c}23 \\
23 \\
\end{array}$ & $\begin{array}{l}\text { 't' } 1.76 \\
\text { 'p' ns }\end{array}$ & $\begin{array}{lr}\text { 't' } & 0.98 \\
\text { 'p' } & \text { ns } \\
\end{array}$ & $\begin{array}{lr}t & 1.27 \\
\text { 'p' } & \text { ns } \\
\end{array}$ & $\begin{array}{l}\text { 't' } 0.5 \\
\text { 'p' ns }\end{array}$ \\
\hline 2 & $\begin{array}{l}\text { Malign } 10 \text { days after } \mathrm{Rx} \\
\text { Vs malign } 20 \text { days after } \mathrm{Rx}\end{array}$ & $\begin{array}{c}23 \\
23\end{array}$ & $\begin{array}{l}\text { 't' } 1.68 \\
\text { 'p' ns }\end{array}$ & $\begin{array}{l}\text { ‘t' } 1.47 \\
\text { 'p' } \quad \text { ns }\end{array}$ & $\begin{array}{l}\text { 't' } 0.33 \\
\text { 'p' ns }\end{array}$ & $\begin{array}{l}\text { 't '1.68 } \\
\text { 'p' ns }\end{array}$ \\
\hline 3 & $\begin{array}{l}\text { Malign } 20 \text { days after } \mathrm{Rx} \\
\text { Vs malign before } \mathrm{Rx}\end{array}$ & $\begin{array}{c}23 \\
23\end{array}$ & $\begin{array}{l}\text { 't' } 3.57 \\
\text { 'p'<0.001 }\end{array}$ & $\begin{array}{l}\text { 't t' } 2.18 \\
\text { 'p'<0.05 }\end{array}$ & $\begin{array}{l}\text { 't' } 1.78 \\
\text { 'p' ns }\end{array}$ & $\begin{array}{l}\text { 't' } 1.0 \\
\text { 'p' ns }\end{array}$ \\
\hline 4 & $\begin{array}{l}\text { Malign } 20 \text { days after Rx } \\
\text { Vsmalig before } \mathrm{Rx}\end{array}$ & 23 & $\begin{array}{l}\text { 't' } 6.18 \\
\text { 'p'< } 0.001\end{array}$ & $\begin{array}{l}\text { 't' } 2.26 \\
\text { 'p'<0.05 }\end{array}$ & $\begin{array}{l}\text { 't' } 3.85 \\
\text { 'p'<0.001 }\end{array}$ & $\begin{array}{l}\text { 't' } 1.9 \\
\text { 'p 'ns }\end{array}$ \\
\hline
\end{tabular}


Table-7: ' $t$ ' and ' $p$ ' values in total malignancies and different groups of malignancies of various parameters compared with controls

\begin{tabular}{|c|c|c|c|c|c|c|}
\hline S. no & Group & $\begin{array}{l}\text { No.of } \\
\text { cases }\end{array}$ & TSA & LASA & LDH & Total proteins \\
\hline 1 & $\begin{array}{l}\text { Benign tumours } \\
\text { Vs Malignancies }\end{array}$ & $\begin{array}{l}20 \\
92\end{array}$ & $\begin{array}{l}\text { 't' } 7.34 \\
\text { 'p' }<0.001\end{array}$ & $\begin{array}{l}\text { 't '2.76 } \\
\text { 'p'<0.01 }\end{array}$ & $\begin{array}{l}\text { 't } \mathrm{t} ' 13.05 \\
\text { 'p'<0.001 }\end{array}$ & $\begin{array}{l}\text { 't '3.26 } \\
\text { 'p'<0.001 }\end{array}$ \\
\hline 2 & Non malign Vs malign & $\begin{array}{l}30 \\
28\end{array}$ & $\begin{array}{l}{ }^{\prime} t \cdot 7.12 \\
\text { 'p'<0.001 }\end{array}$ & $\begin{array}{l}{ }^{\prime} t ' 11.23 \\
' p '<0.001\end{array}$ & $\begin{array}{l}\text { 't' } 0.47 \\
\text { 'p' }<0.001\end{array}$ & $\begin{array}{l}\cdot \mathrm{t} \cdot 0.46 \\
\mathrm{p} \text { 'ns }\end{array}$ \\
\hline 3 & Control Vs malign & $\begin{array}{l}30 \\
92\end{array}$ & $\begin{array}{l}\text { 't' } 12.7 \\
\text { 'p'<0.001 }\end{array}$ & $\begin{array}{l}\text { t } 5.98 \\
\text { 'p'<0.001 }\end{array}$ & $\begin{array}{l}\text { t } 11.21 \\
\text { 'p'<0.001 }\end{array}$ & $\begin{array}{l}\text { 't' } 3.1 \\
\text { 'p'<0.01 }\end{array}$ \\
\hline 4 & Controls Vshead\&neckmalig & $\begin{array}{l}30 \\
28 \\
\end{array}$ & $\begin{array}{l}1 \\
\text { 't'9.45 } \\
\text { 'p'<0.001 }\end{array}$ & $\begin{array}{l}\text { ' t' } 5.38 \\
\text { 'p'<0.001 }\end{array}$ & $\begin{array}{l}\text { ' t' } 6.8 \\
\text { 'p'<0.001 }\end{array}$ & $\begin{array}{l}\text { 't' } 1.0 \\
\text { ‘p' ns }\end{array}$ \\
\hline 5 & $\begin{array}{l}\text { Control Vs Female genital tract } \\
\text { malign }\end{array}$ & $\begin{array}{c}30 \\
22\end{array}$ & $\begin{array}{l}\text { 't t' } 8.05 \\
\text { 'p'<0.001 }\end{array}$ & $\begin{array}{l}\text { 't'3.15 } \\
\text { 'p'<0.01 }\end{array}$ & $\begin{array}{l}\text { 't' } \mathrm{t} 9.85 \\
\text { 'p'<0.001 }\end{array}$ & $\begin{array}{l}\text { 't' } 1.47 \\
\text { 'p'ns }\end{array}$ \\
\hline 6 & Control Vs GIT malign & $\begin{array}{c}30 \\
16\end{array}$ & $\begin{array}{l}\mathrm{t} 8.84 \\
\text { 'p'<0.001 }\end{array}$ & $\begin{array}{l}\text { t } 5.35 \\
\text { 'p'<0.001 }\end{array}$ & $\begin{array}{l}\mathrm{t} 7.71 \\
\text { 'p'<0.001 }\end{array}$ & $\begin{array}{l}\text { 't } \mathrm{t} \text { '3.60 } \\
\text { 'p'<0.001 }\end{array}$ \\
\hline 7 & Control Vs other malig & $\begin{array}{l}30 \\
16\end{array}$ & $\begin{array}{l}\mathrm{t} 10.06 \\
\text { 'p' }<0.001\end{array}$ & $\begin{array}{l}\text { t } 3.9 \\
\text { 'p'<0.001 }\end{array}$ & $\begin{array}{l}\text { t } 6.13 \\
\text { 'p'<0.001 }\end{array}$ & $\begin{array}{l}\text { 't'3.09 } \\
\text { 'p'<0.01 }\end{array}$ \\
\hline 8 & Control Vs breast mali & $\begin{array}{l}30 \\
10 \\
\end{array}$ & $\begin{array}{l}\text { ' } t \text { ' } 4.74 \\
\text { 'p'<0.001 }\end{array}$ & $\begin{array}{l}\text { ' t' } 3.63 \\
\text { 'p'<0.001 }\end{array}$ & $\begin{array}{l}\text { 't' } 3.14 \\
p<0.01\end{array}$ & $\begin{array}{l}\text { 't' } 1.03 \\
\text { 'p' ns }\end{array}$ \\
\hline
\end{tabular}

\section{Discussion}

Malignant cell surface glycoproteins and glycolipids have altered carbohydrate composition that may contribute to aberrant cell-cell recognition, cell adhesion, antigenicity and the invasiveness demonstrated by malignant cells, released into sera through increased tumour secretion or shedding and thus are considerable interest for their potential diagnostic and prognostic value (5) (17).

Pluconskyetal have reported significant elevation of TSA and LASA in malignances. We have also observed an increased serum TSA and LASA in malignant patients (14). Sialic acid is an acute phase glycoportein so their levels are increased in non malignant diseases, in this study TSA increased in non malignant diseases but lower the LASA and there is no significant difference of LASA values in non malignancies and controls. (6) (7) (8).

Sialic acid concentrations are significantly higher in malignant tumours than in benign tumors. The sialic acid levels in benign tumours are no significance different from those of healthy controls (15). It has also been suggested that changes in the sialic acid content of patients sera reflect growth process of benign and malignant character. (8) (9).

LDH through sensitive is not a specific marker because its concentration increase in several diseases. (12) in this present study we found higher levels of LDH in non malignant diseases and there is no statistically significant difference between malignant and non malignant diseases. (16) decreased protein values in nonmalignant and there is no statistically significant difference in protein values in malignance and non-malignance. These findings indicate their non specificity. (19).

The concentration of sialic acids are related to malignant cell. So sialic acid concentrations are higher in advanced stages of malignancies than in earlier stages. (19) In this study we find out of TSA and LASA are gradually decreased in serial measurements in followed up cases. The decrease is statistically significant at the end of 20 days after treatment.

The sialic acid concentrations should be useful in monitoring the progress of the disease. This study showed decreases to sialic acid concentrations after effective treatment. (28) Our data showed lower utility of LDH as a diagnostic marker. (21) However we found that when LDH is used in combination with the TSA or LASA has increased their diagnostic potential (22).

The availability of simple and less expensive tumor markers and it is quite useful in routine diagnosis and monitoring malignancies as well as mass screening for malignancies.

\section{Conclusions}

The serum TSA and LASA values are significantly increased in malignancies compared to the controls indicating altered metabolism of tumor cell surface glycoproteins and sialoglycolipids. Thus TSA is a sensitive marker to evaluate the disease progression or regression in response to treatment. TSA in combination with LDH showed best diagnostic potential.

\section{Bibliography}

[1]. Baumann, H and Nudelman, E etal; Cancer Res. 39; 2637, 1979.

[2]. Bremier, M.E Cancer Res 40: 897, 1980

[3]. Dnistrain A.M and Schwartz, M.Ketal Serum lipid bound sialic acid as a marker in breast cancer.Cancer 50: $1815,1982$.

[4]. Henry R.J. Sobel. C.S Berkman S. etal Determination of serum proteins by the biuret reaction. Anal chem. $92.1491-1957$ 
[5]. Hakomor. S. Tumour associated carbohydrate antigens. Annual review of immunology 2:103, 1984.

[6]. Hakomor. S. TumorGlycosphingolipids in cellular interaction. Differentiation and oncogenesis. Annual review of Biochem. 50:733, 1981.

[7]. Harvey. H.A. Lipton, A, Glycoproteins and human cancer, correlation between circulating level and disease status.Cancer47:324, 1981

[8]. Katopodis N. Stock C.C. Improved method to determine lipid bound sialic acid in plasma or serum.Res common chem. Path pharmacol 30:171, 1980.

[9]. Katopodis N. Hirshaunt. Y. Gellen N.I lipid associated sialic acid test for determination of human cancer.Research 42: 5270, 1982.

[10]. King J. Colorimetric method for determination of serum LDH in practical clinical enzymology. 1965.

[11]. Opez. L.S. Senra. J. evaluation of lipid bound sialic acid as tumour marker j. boil marker 10:174, 1985

[12]. Patel P.S. Rawal G.N. Rolar D.B. importance of serum sialic acid and LDH in diagnosis and treatment monitoring cervical cancer patients. GynaecologyOncol 50:174, 1995.

[13]. Plucinsky M.C. riley. W.M. etal : total and lipid associated serum sialic acid in cancer patients with different primary sites and differing degrees of metastatic involvement. Cancer 58: 2680, 1985.

[14]. Stefenelli N. Klotz, Engel. A. Bauer. P. serum silli acid in malignant tumours bacterial infections and chronic liver diseases. J. cancer Res. Clinical oncol. 109: 55, 1985.

[15]. Sharmberger R.J. Serum sialic acid in normal's and cancer patients. J. Clinchemcliniochem 22:647, 1984.

[16]. Schutter E.M. Visser J.J. etal in utility of lipid associated sialic acid as serum markter for malignancy. TumourBiol 13: 121 , 1992

[17]. Spiegel. S. Ravid. A. Involvement of gangliosides in lymphocyte stimulation. Proc. Natl. Acid - Sci USA 76: 5277, 1979

[18]. Silver H.K.B. Rengel D.M. and mortion. L serum sialic acid evaluation in malignant melanoma patient. Cancer 41: 1497, 1978 .

[19]. Tewarson S.L. etal serum sialic acid in important cancer marker.Ind. J. of Cancer 30:125, 1993.

[20]. Tautu. C. Pee, D. Dunsmoretal. Evaluation of serum sialic acid and CEA for the detection of early stage colorectal cancer. J. Cli.lab. Anal 5: 247, 1991Xing R.D. Chen R.M. etal

[21]. Serum Sialic acid levels in patients with oral maxilla facial malignancy J. oral maxilla fac. Surg.19: 843, 1991

[22]. Yogeswaram G. cell surface glycolipids and glycoproteins in malignant transformation Adv. Cancer Res. 38:289, 1983 